\title{
The Differences of Student Learning Result by Using Cooperative Learning Model of Team Games Tournament Type and Conventional Learning Model
}

\author{
Robet Kennedi Sianipar. \\ The student of Graduated Program of \\ Universitas Negeri Medan, \\ Medan, Indonesia \\ Email: robertkenedy65@gmail.com
}

\author{
Syafari. \\ Graduated Program \\ Universitas Negeri Medan \\ Medan, Indonesia
}

\begin{abstract}
A strong mathematics mastery of an early age is required to equip students with logical, systematic and creative analytical skills. Reasoning ability in understanding is required in learning mathematics. This study aims to determine student mathematics learning result by using cooperative learning model of Team Games Tournament type of grade 7 of Sei Rampah Junior High School number 1 (one) in doing algebra operation. The research of this study is experimental based research which is the differences of student learning result by using cooperative learning model of Student Teams Achievement Division type with conventional learning model. The result of learning obtained after the students are given a test at the end of the study. The instrument used by the author to obtain data is a test.From the result, the author found that the quality of questions is good since the instrument used is valid and the data of the result from both group are distributed normally. From two test held, there were two samples are found clearly different. Based on the analysis, the author concludes that there is significant difference of student mathematics learning result by using cooperative learning model of TGT type with conventional learning model.
\end{abstract}

Keywords: learning result, cooperative learning, conventional learning

\section{INTRODUCTION}

Education is basically an effort to provide the knowledge, insight, skills and other specific skills for individuals to develop their talents and personality. Education makes people expend themselves to be able to face any changes caused by the advancement of science and technology. This remark mentioned by the author in [3] which states "National education was function to develop the ability, character and civilization of the dignified nation in program to educate the life of the nation, the purpose of the development of learners to be a human who believes and devout to almighty god, to be honorable, healthy, Knowledge able, capable, creative, independent and become a democratic and responsible citizen ". The author in [11] says that mathematics (science of definite) for children in general is a subject that is unpopular, important to understand. This condition give the illustrates of the lack of mathematical and scientific ability, which can result in low student competitiveness in te context of science development if not as a hated subject. In accordance with the authors' statement [1] that: "Of the various subject of study taught in schools, Mathematics is a subject of study that was considered as the most difficult for students, both for student who don't find the difficult on this subject and for students with learning difficulties". From the it can be conclude that students regard mathematics as a difficult subject. Mathematic mastery that strongly mastered since early age is necessarily to equip students with logic, analytical, systematic, and creative thinking skills. the author in [10] saw that mathematics is an abstract, axiomatic and deductive science. Since mathematics is abstract, it can be a cause of difficulties among students in learning and understand mathematic concept. Based on the result of International Student Assessment Program in 2012, Indonesia is ranked $64^{\text {th }}$ out of 65 countries that participated the test [5].

The ability of Indonesian children at the age of 15 in the field of mathematics, science and reading is still low comparing with other children in other part of the world. For the learning process to succeed, the teacher must guide the students and optimize the teaching and learning resources. Besides, it needs a proper model of learning because the learning model is a means of interaction of teachers and students in teaching and in learning activities.

The use of appropriate learning model will lead a good learning result. The teachers should be able to design how students can participate in learning, among others through cooperative learning model.

The one of the cooperative learning model of Teams Game Tournament is really suitable to be applied in junior high school according to the author's observation at the time before finishing the research. According to author in [9], Team Games Tournament has a dimension of excitement that is gained from the game it self. This learning model involves participation of all students without any discrimination, involving the role of the students as a peer tutor, containing an element of the game. 
This learning model can foster a sense of responsibility, cooperation and fair competition. Although the research evidence highlights the positive and significant results of TGT use in education, it appears to be a study of its use in limited teaching and learning mathematics. The author in [2] The most of the research in algebra teaching and learning, graphics and functions, straight lines, geometry, trigonometry, statistics and calculus. The author in [10] conducted her study to compare cooperative and conventional learning models. Her findings show that students who learn by using cooperative learning is perceiving it positively. According to author in [11], cooperative learning is when students of various levels of ability are grouped together in smaller groups. The author in [13] in her study used cooperative TGT in a mathematics classroom at a public secondary school. This model encourages students to be more competitive, work together with the other, and to be more active as well as creative in their learning. Their findings show that students who use the TGT cooperative model performed better than those who under gone the conventional learning model.

The TGT cooperative learning model consists of three main components, namely class presentation, group and academic competition. A study by author in [11] found that the teaching of mathematics needs specific understanding in defining conceptual reasoning through analysis and interpretation to prove the effectiveness of student participation in a classroom discussion.

The author in [14] in their study showed that working memory, smoothness of activities and non-verbal reading comprehension are the main contributors towards the problem of grasping the mathematical concept, especially at secondary school level. The findings of the study carried out by the Institute of Education Sciences (2010), show that there is a positive relationship between Cooperative Integrated Reading and Composition (CIRC) instruction and student performance. The author in [7] finding the use of the IMPROVE (Introducing new concepts, Meta cognitive questioning, Practicing, Reviewing and Reducing difficulties, Obtaining mastery, Verification, \& Enrichment) method has increased secondary school students comprehension, communication and mathematics achievement compared to the conventional approach . Also, the finding by author in [1], using the Think-Talk-Write (TTW) strategy in small groups, shows an increase in comprehension and communication compared to the conventional approach. Based on the description, the author wants to answer whether there are differences in student learning results by using cooperative learning model of TGT type with conventional learning model.

\section{METHOD}

One of the type of learning models is Team Games Tournament (TGT). It is developed by David De Vries and Keath Edward. At this model of learning, members of different team play the game to get the additional point. According to author in [6], TGT is one of cooperative learning which put student in different level of ability, gender, race, where all the members of the team should take responsibilities to help their team mates. Mean while, according to author in [9], TGT is one of cooperative learning which uses academic tournament where the students stands for their own team competing with other team in a competition. According to those experts as a conclusion, that TGT is one of the cooperative learning model that put the students in different level of ability, gender, race, in a team to compete in an academic tournament. In order for students to be able to apply TGT in class, simplification of the learning process is needed.

The author in [9] stated that there are several types of TGT based learning model such as ; Teaching : delivering the learning materials, Learning in Team :the students do work sheets in terms of learning material acquisition, Tournament :the students play three players table academic game, Recognition of Team : the score of the team counted individually based on the team members' score as the team will be recognised if they can full fill the game's scoring terms mentioned before the game.

The steps of TGT learning model according to those two experts mentioned previously are simply the same. At this first step, the learning materian is taught by teacher by doing presentation in front of the classroom just like teaching learning process commonly applied. Introductory to the learning material is given limited, just to give the students brief overview of the learning material they are going to learn.

Those two expert points of view of TGT learning model is just the same. At these steps, all the members of teams work together and help one another to understand the learning material they are learning.

The third step is tournament. Tournament is held either at the end of every unit of the lesson or when the teacher has done the class presentation as well as the groups of study have the learning process done. Top three students from different group will be seated and stand for their group in the competition so that the competition could run competitively.

Each team in the tournament consists of three member, they are reader, first challenger, and the second challenger. The duty of the reader is to find the numbered card and to find the question on the game board then to read the question as well as to give the answer to the question. The duty of the first challenger is to state the agreement of the reader's answer and to give different answer. The duty of the second challenger is to state the agreement of the reader's answer and to give different answer as well as to check the answer sheet. This kind of activity is held take turns. For the correct answer will be given 1 point and for the wrong answer will be given 0 point. The tournament will be ended either when the numbered card is finished or the time given is over.

This research type is quasi experimental research, it is the difference of student learning result which use cooperative learning model of TGT type and conventional learning model. The learning results in question are the values achieved by the students after being given the test at the end of the study. The instrument used by the author to obtain the data is the test. The test that used is an objective test. It is a 
multiple choice test with 20 questions. Each question has four alternative answers. For a correctly answered question is given a score of 1 and for a wrong answer is given a score of 0 so the maximum score is 20 .

The population of this research is 373 . Randomly 44 students are taken that they were doing experimental class by using TGT learning model and 41 students were doing controlling by using conventional learning model.

To find out whether the data came from populations are the same (homogeneous) or not, a variance homogeneity test was held (two-variance equality test) with hypothesis:

Ho: $\sigma_{1}^{2}=\sigma_{2}^{2}$

Means, there is no significant difference between variance sample of the TGT model of cooperative learning model and the conventional learning model.

Ha: $\sigma_{1}^{2} \neq \sigma_{2}^{2}$

Means, there is a significant difference between variance sample of the TGT of cooperative learning model and the conventional learning model.

The research hypothesis for this two-difference test is:

$H_{0}: \mu_{1}=\mu_{2}$

Means, the average of learning result of the sample of cooperative learning model of TGT type and the conventional learning model differ significantly.

\section{RESULT}

The two models of learning, TGT learning model and Conventional learning model statistically shown as follow below in table number 1 .

Table 1.

Research Statistic Data

\begin{tabular}{|l|l|l|}
\hline $\begin{array}{l}\text { Types of } \\
\text { Statistic }\end{array}$ & $\begin{array}{l}\text { Experimental Class } \\
\text { (TGT Learning Model) }\end{array}$ & $\begin{array}{l}\text { Controlling Class } \\
\text { (Conventional Learning } \\
\text { Model) }\end{array}$ \\
\hline $\begin{array}{l}\text { N (Number of } \\
\text { Data) }\end{array}$ & 44 & 41 \\
\hline Average & 12,568 & 10,902 \\
\hline Variance & 6,483 & 6,29 \\
\hline Deviation & 2,546 & 2,508 \\
\hline Highest Score & 16 & 15 \\
\hline Lower Score & 6 & 5 \\
\hline
\end{tabular}

Based on statistic data shown above, both the average score of samples are noticeably. The average of experimental class is 12,568 and the average of controlling class is 10,902 . Based on the result of the research, lots of students' score of the Experimental class are above the average which is 26 students $(60,46 \%)$ while in Controlling class, student who got score above the average is 24 students $(58,54 \%)$. It can be concluded that the result of TGT learning model is better than the Conventional Learning model.

As for the result of this research are:

1. Student learning result in mathematic is by using cooperative learning model of Team Games Tournament in algebra operation of the $7^{\text {th }}$ graders of Sei Rampah
Junior High Public School number 1 (one). The average of the experiment class is 12,568. Students who got the score above the average is 26 students or $60,46 \%$.

2. Student learning result in mathematic is by using conventional learning model in algebra operation of the $7^{\text {th }}$ graders of Sei Rampah Junior High Public School number 1 (one) is fairly enough. The average of controlling class is 10,902 . Many students who got the score above the average is 24 students or $58,54 \%$.

\section{CONCLUSION}

The conclusion of this research is that there is a significant difference between student mathematics learning result by using cooperative learning model of TGT type and students learning result by using conventional learning model in the algebra operation where the result of students who learn mathematic by using TGT learning model is better than the result of student who learn by using conventional learning model. This study is in line with the authors of [12] who say that the average score of students' learning independence on cooperative learning type TGT includes high criteria, improved reasoning ability and mathematical connections of learners who follow cooperative learning type TGT better than those who follow direct learning, There is no interaction of TGT type cooperative learning model and direct learning model to improve students' mathematical reasoning ability, and there is interaction of cooperative learning model of TGT type and direct learning model to the improvement of mathematic connection ability of learners.

\section{REFERENCES}

[1] Ansari, B.I. (2004). Menumbuh kembangkan Kemampuan Pemahaman dan Komunikasi Matematis Siswa SMU melalui Strategi Think-TalkWrite. Disertasi Doktor pada PPS UPI Bandung: not published.

[2] Arnold S (2008). Making algebra meaningful with technology. Paper presented at the 3rd national conference of graphing calculators.

[3] Depdiknas. 2003. Kurikulum Berbasis Kompetensi Mata Pelajaran Matematika. Jakarta. Pusat Kurkulum. Balitbang Depdiknas.

[4] Mc Glaughlin, Andrew \& Holiday (2005). Differentiating Students With Mathematics Difficulty In College: Mathematics Disabilities vs. No Diagnosis. University of Missouri-Columbia.

[5] PISA (Programme for International Student Assessment) http://www.kopertis12.or.id/2013/12/05/skor-pisa-posisi-indonesianyaris-jadi-juru-kunci.html

[6] Rusman. 2012. Model-model Pembelajaran Mengembangkan Profesionalisme Guru. Jakarta: Rajawali Pers.

[7] Rohaeti, E.E. (2003). Pembelajaran Matematika dengan Menggunakan Metode IMPROVE untuk Meningkatkan Pemahaman dan Kemampuan Komunikasi Matematis Siswa SMP.Thesis pada PPS UPI Bandung: not published.

[8] Ruseffendi, E.T. 2001. Dasar-dasar Penelitian Pendidikan dan Bidang Non Eksakta Lainnya. Semarang: IKIP Semarang Press.

[9] Slavin, Robert (2005).Cooperative Learning Teori, Riset dan Praktik. Bandung : Nusa Media.

[10] Suhaida Abdul Kadir. (2002). "Perbandingan Pembelajaran Koperatif Dan Tradisional Terhadap Prestasi, Atribusi Pencapaian, Konsep Kendiri.Akademik Dan Hubungan Sosial Dalam Pendidikan Perakaunan”.Universiti Sains Malaysia: Tesis Sarjana Muda

[11] Uno, Hamzah (2007). Model pembelajaran menciptakan proses belajar mengajar yang efektif dan kreatif. Jakarta : Bumi Aksara. 
[12] Tok Hoon Seng (2006). “Cooperative Learning And Achievement In English Language Acquisition N A Literature Class In A Secondary School”. Universiti Teknologi: Tesis Sarjana Muda.

[13] Van Es Elizabeth, A., \& Conroy J. (2009). Using the Performance Assessment for California Teacher to Examine Pre-Service Teacher Conceptions of Teaching Mathematics For Understanding”. Issues in Teacher Education. University of California, Irvine.
[14] Wikanengsih.(2005). Pembelajaran Kooperatif Tipe Teams-GamesTournament (TGT) dalam Pembelajaran Membaca Pemahaman sebagai Upaya untuk Meningkatkan Kemampuan Membaca Siswa.Tesis PPS UPI Bandung: not published. 